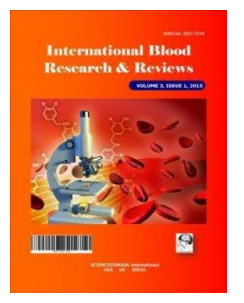

International Blood Research \& Reviews

3(4): 166-170, 2015, Article no.IBRR.2015.019

ISSN: 2321-7219

SCIENCEDOMAIN international

www.sciencedomain.org

\title{
Severe Hemolytic Anemia Due to De novo Hemoglobin Sabine in an Argentinian Newborn. First Case in South America
}

\author{
Susana Perez ${ }^{1 *}$, Irma Bragós ${ }^{1}$, Mariana Raviola ${ }^{1}$, Arianna Pratti ${ }^{1}$, \\ Germán Detarsio ${ }^{1}$, Sandra Zirone ${ }^{2}$, Maria Eda Voss ${ }^{1}$, Luciano Verón ${ }^{2}$, \\ Irma Acosta ${ }^{1}$ and Mara Ojeda ${ }^{1}$
}

${ }^{1}$ Departamento de Bioquímica Clínica, Cátedra de Hematología, Facultad de Ciencias Bioquímicas y Farmacéuticas, Universidad Nacional de Rosario. Suipacha 531. Rosario. Santa Fe, Argentina. ${ }^{2}$ Departamento de Hematología, Instituto Davoli. Laprida 1061. Rosario. Santa Fe, Argentina.

\section{Authors' contributions}

This work was carried out in collaboration between all authors. Authors SP and IB designed the study, wrote the protocol, wrote the first draft of the manuscript, managed the analyses of the study and managed the literature searches. Authors MR, MO, LV, IA and AP performed laboratory tests. Authors $A P, G D, S Z$ and MEV managed the literature searches.

Article Information

DOI: $10.9734 / I B R R / 2015 / 18559$

Editor(s):

(1) Ricardo Forastiero, Department of Hematology, Favaloro University, Argentina

(1) Mathew Folaranmi Olaniyan, Department of Medical Laboratory Science, Achievers University, Owo, Nigeria.

(2) Vlachaki Efthymia, Department of Internal Medicine, Aristotle University, Greece. Complete Peer review History: http://www.sciencedomain.org/review-history.php?iid=1082\&id=28\&aid=9551

\begin{abstract}
Hemoglobin $(\mathrm{Hb})$ Sabine is an unstable $\mathrm{Hb}$ variant that causes hemolytic anemia in heterozygous state, with inclusion bodies in the red blood cells (RBC). This hemoglobin is the result of a point mutation at codon 91 (CTG) $\rightarrow$ (CCG) of the beta-globin gene. We report, for the first time in South America, the identification of $\mathrm{Hb}$ Sabine in a nine-month-old female baby, referred to our laboratory bearing a severe hemolytic anemia. We emphasize the need for the correct characterization of this unstable hemoglobin mainly for therapeutic purposes and for genetic counseling.
\end{abstract}

Keywords: Abnormal hemoglobin (Hb); Hb sabine; unstable hemoglobin.

${ }^{*}$ Corresponding author: E-mail: perezsusanamabel@gmail.com; 


\section{INTRODUCTION}

Up to date, there have been described more than 140 unstable hemoglobins [1], related to hemolytic anemia with different clinical expression. The mutations that cause destabilization of the tetrameric structure are the most frequent cause of hemolytic anemia. Proline introduction in the alpha helix, beyond the third residue, distorts the hemoglobin structure and cause instability. In general, these undergo increased oxidation of the heme with the formation of met $\mathrm{Hb}$ and further degradation leading to precipitated $\mathrm{Hb}$ and other products within the circulating red cells. [2] In $\mathrm{Hb}$ Sabine, as in many of the other unstable hemoglobins, the substitution is a neutral one $[\beta 91(\mathrm{~F} 7)$ Leu+Pro], so no alteration in charge of the globin chain would be expected. The diminished anodal mobility of these hemoglobins is probably due to loss of heme, an event to which they are peculiarly prone [3]. Hb Sabine is an unstable $\beta$ chain variant which causes moderately severe hemolytic anemia and has been reported in a few unrelated patients, none of them from South America till date [4-8]. In this paper, we report a new de novo case of $\mathrm{Hb}$ Sabine in a nine-monthold female baby. The mutation was identified by DNA sequencing following amplification by polymerase chain reaction (PCR). The proband's father is of German origin and her mother is of Spanish descent. The girl has no familial history of anemia. Paternity was confirmed through studies of DNA polymorphism (STRs loci).

\subsection{Case Report}

The child was admitted to the Service of Pediatrics because of a moderately severe anemia, pallor and a subicteric condition. Her facies indicates expansion of haemopoietic tissue in the skull bones, particularly in the frontal and parietal bones. She had never been transfused. At the age of seven months, she suffered a hemolytic episode in the course of an infection.

Hematological data were obtained with a Sysmex KX21 blood counter. The blood film showed microcytosis, polychromasia, target cells, coarse basophilic stippling, and 2 nucleated erythroid progenitors per 100 white cells. The $\mathrm{Hb}$ A2 was measured by elution post electrophoresis at alkaline $\mathrm{pH}$, and $\mathrm{Hb} \mathrm{F}$ according to the method described by Betke et al. [9].

Isopropanol test (Carrell \& Kay) [10] was performed. Cellulose acetate electrophoresis at alkaline $\mathrm{pH}$ and globin chains electrophoresis at alkaline $\mathrm{pH}$ were carried out using standard methods.

Sickling test was negative. The isopropanol test was positive indicating the presence of an unstable $\mathrm{Hb}$. Cellulose acetate $(\mathrm{pH}$ 8.4) electrophoresis detected an additional $\mathrm{Hb}$ fraction, between $\mathrm{Hb} A$ and $\mathrm{Hb}$ A2. (Fig. 1) Globin chains electrophoresis did not show the presence of an abnormal chain.

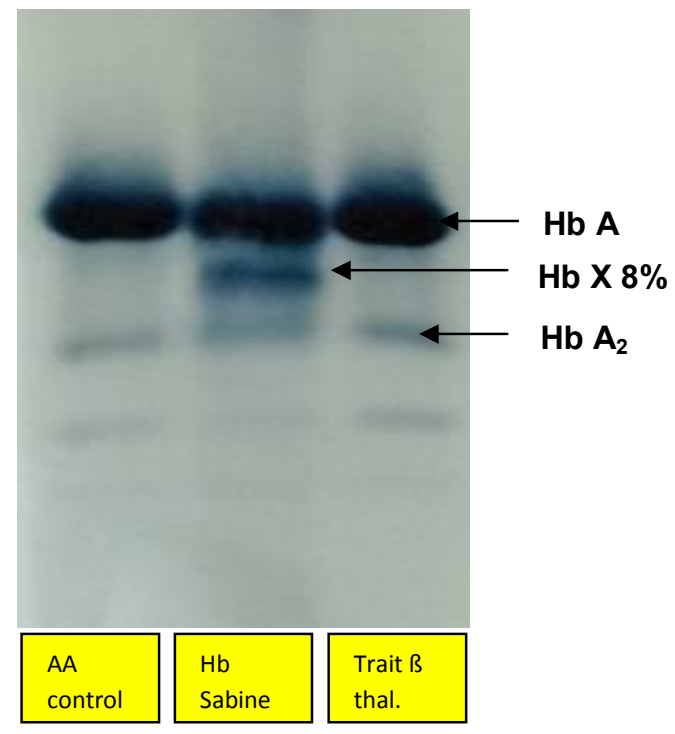

Fig. 1. Hemoglobin electrophoresis at alkaline pH 
The patient's hematological and biochemical data are shown in Table 1 and hematological and hemoglobin composition data of parents are shown in Table 2.

DNA was extracted from peripheral blood samples as previously described [11]. Polymerase chain reaction (PCR) was carried out and then the coding regions of the $\beta$ - and $\alpha$ globin genes were sequenced. It was performed using a Big Dye Terminators Ready Reaction Kit
(Perkin-Elmer Cetus, Norwalk, CT, USA) in an ABI PRISM 310 sequencer (Perkin-Elmer Cetus).

Alpha1 and $\alpha 2$ genes were normal, while sequencing of $\beta$ gene revealed a $\mathrm{CTG} \rightarrow \mathrm{CCG}$ (Asp $\rightarrow$ His) substitution at codon 91, corresponding to $\mathrm{Hb}$ Sabine (Fig. 2). DNA sequence analysis of the ß-globin gene of both parents showed the absence of the $\mathrm{Hb}$ Sabine mutation. Paternity was confirmed by the study of nine short tandem repeats (STRs) and four variable-number tandem repeat (VNTRs) loci.

Table 1. Hematological and biochemical data of the patient

\begin{tabular}{ll}
\hline Parameters & Proband \\
\hline $\mathrm{Hb}$ A/X/A2 (\%) & 8 \\
$\mathrm{Hb}(\mathrm{g} / \mathrm{L})$ & 770 \\
$\mathrm{RBC}\left(10^{12} / \mathrm{L}\right)$ & 2.84 \\
$\mathrm{MCV}(\mathrm{fL})$ & 95.1 \\
$\mathrm{MCH}(\mathrm{pg})$ & 27.1 \\
Reticulocytes (\%) & 40 \\
$\mathrm{~A} 2(\%)$ & 2.6 \\
$\mathrm{Hb}$ F (\%) & 10 \\
Isopropanol Test & positive \\
Sickling Test & negative \\
Total serum bilirrubina (umol/L) & $35.2(\mathrm{NR}: 5.7-17)$ \\
LDH U/l & $1075(\mathrm{NR}: 360-720)$ \\
Ferritina (ug/dl & $84(\mathrm{NR}: 24-120)$ \\
Iron (ug/dl) & $114(80-110)$ \\
TIBC (ug/dl) & $351(280-330)$ \\
\hline
\end{tabular}

Table 2. Hematological and hemoglobin composition data of parents

\begin{tabular}{|c|c|c|c|c|c|c|c|c|}
\hline Subjet & $\mathrm{Hb} \mathrm{g} / \mathrm{L}$ & $\begin{array}{l}\text { RBC } \\
\left(10^{12} / \mathrm{L}\right)\end{array}$ & $\begin{array}{l}\text { MCV } \\
\text { (fL) }\end{array}$ & $\begin{array}{l}\mathrm{MCH} \\
(\mathrm{pg})\end{array}$ & $\begin{array}{l}\text { Reticulocytes } \\
(\%)\end{array}$ & A2 (\%) & $\begin{array}{l}\text { Hb F } \\
(\%)\end{array}$ & $\begin{array}{l}\mathrm{Hb} X \\
(\%)\end{array}$ \\
\hline Father & 152 & 4.8 & 91.7 & 31.7 & 1.3 & 2.4 & 1 & 0 \\
\hline Mother & 134 & 4.27 & 88 & 31.4 & 1.2 & 2.6 & 0.9 & 0 \\
\hline
\end{tabular}
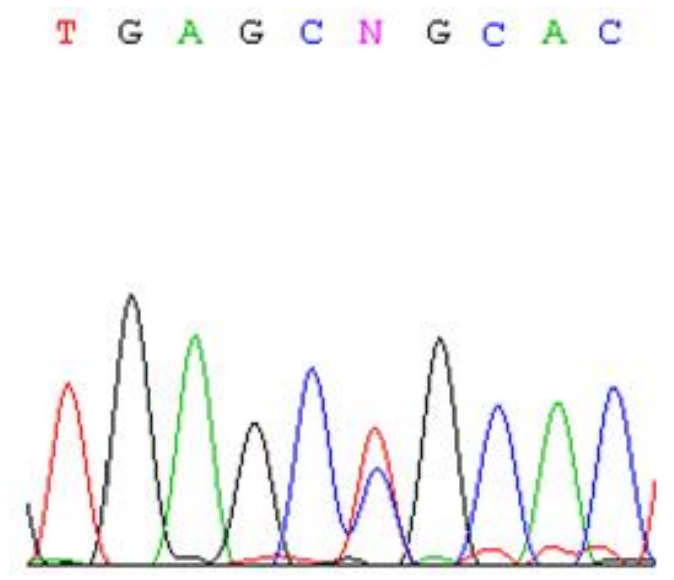

Fig. 2. Sequence of the $\beta$-globin gene: CTG $\rightarrow$ CCG (Asp $\rightarrow$ His) substitution at codon 91 corresponding to $\mathrm{Hb}$ Sabine 


\section{DISCUSSION}

Numerous cases of hemolytic anemia have been described that are a consequence of the presence in the erythrocyte of unstable hemoglobins.

Most unstable hemoglobin variants in heterozygous state have a variable percentage of the variant. In our case it was $8 \%$ of total hemoglobin. This is a much smaller proportion than that found for most $\mathrm{Hb}$ variants, presumably because it is precipitated both in vivo and in vitro during manipulation in the experimental procedures. The erythrocyte containing $\mathrm{Hb}$ Sabine, have a markedly shortened survival as a consequence of impaired metabolism, probably due to dissociation and precipitation of abnormal beta polypeptide chains of $\mathrm{Hb}$ Sabine. Unstable $\mathrm{Hbs}$ are inherited in an autosomal dominant fashion, and virtually all affected individuals are heterozygous. The homozygous state for the unstable variants has not been found.

Our patient, as all $\mathrm{Hb}$ Sabine carriers reported so far had significantly increased $\mathrm{Hb} F$ levels ( $\mathrm{HbF}: 10 \%)$ Patients with higher levels of $\mathrm{HbF}$ as those refered by Pavlovic $S$ el al. [8] and Panagoula Kollia et al. [12] one had an association with the $\mathrm{Xmn}$ I polymorphism at -158 Gy and the other a compound heterozigocity with non-deletional hereditary persistence of fetal hemoglobin respectively.

Almost all reported patients suffered from severe hemolytic anemia and were splenectomized at early age.

Our patient that now is 17 months is been managed with folic acid and when she was 14 months received one transfusion. Splenectomy cannot be predicted now, it will depend on the transfusion regimen, hypersplenism and how she passes her early childhood. In Pediatrics is ideal to splenectomize after the age of 6 .

Even though $\mathrm{Hb}$ Sabine is detectable by electrophoresis, its correct characterization requires more sophisticated methods, like high performance liquid chromatography, capillary electrophoresis or molecular analysis.

The so far published cases of $\mathrm{Hb}$ Sabine in 1969 [4], 1983 [5], 1992 [6] and 2008 [13] were all de novo presentations. The only inherited case reported in 2004, was the son of a Yugoslavian patient [8].

\section{CONCLUSION}

We report this case to emphasize the need for the correct identification of this unstable hemoglobin, mainly for therapeutic purposes and for genetic counseling, especially in therapeutic cases [14-15].

These patients present mild to severe chronic hemolytic anemia that may be exacerbated by stress, especially infections, and treatment with oxidizing agents.

\section{CONSENT}

All authors declare that written informed consent was obtained from the patient's parents for publication of this case report.

\section{ETHICAL APPROVAL}

All authors hereby declare that all laboratoty tests have been examined and approved by the "Comité de Etica de la Facultad de Ciencias Bioquímicas" and have therefore been performed in accordance with the ethical standads laid down in the 1964 Declaration of Helsinki.

\section{COMPETING INTERESTS}

Authors have declared that no competing interests exist.

\section{REFERENCES}

1. Available:http://globin.bx.psu.edu//hbvar// menu.html Hb Var: a database of human hemoglobin variants and thalassemias (Available:http://globin.cse.psu.edu/hbvar/ menu.htm)

2. Beutler E, Lichtman M, Coller B, Kipps T. Hemoglobinopathies associated with unstable hemoglobin, in Wlliams Hemalology $\left(5^{\text {th }}\right.$ ed), edited by. Beutler $E$, Lichtman MA, Coller BS, Kipps TJ. New York, McGraw-Hill. 1995;650-654.

3. Ueda S, Schneider R. Brief Report: Rapid Differentiation of Polypeptide Chains of Hemoglobin by Cellulose Acetate Electrophoresis of Hemolylsates. Blood. 1969;34:230-235.

4. Schneider RG, Ueda S, Alperin $\mathrm{J}$ et al. Hemoglobin Sabine Beta 91 (F 7) Leu $\rightarrow$ Pro-An Unstable Variant Causing Severe Anemia with Inclusion Bodies. N Engl J Med. 1969;280:739-745.

5. Bogoevski P, Efremov GD, Kezic J, Lam H, Wilson JB, Huisman THJ. Hb Sabine or $\alpha 2$ 
ß2 91(F7) Leu-Pro in a Yugoslavian boy. Hemoglobin. 1983;7:195-200.

6. Gasperini D, Galanello R, Melis MA, et al. Hemoglobin Sabine $[\beta$ 91(F7) Leu Pro]: occurrence in a Sardinian individual with hemolytic anemia and inclusion bodies. Haematologica. 1992;77:381-3.

7. Hull D, Winter PC, McHale CM et al. Familial hemolytic anemia due to $\mathrm{Hb}$ Sabine (beta-91(F7)leu-to-pro) identified by polymerase chain reaction. Hemoglobin. 1998;22:263-266.

8. Pavlovic S, Kuzmanovic M, Urosevic $\mathrm{J}$ et al. Severe central nervous system thrombotic events in hemoglobin Sabine patient. Eur J Haematol. 2004;72:67-70.

9. Efremov GD, Huisman THF. Diagnótico de laboratorio de hemoglobinopatías en Hemoglobinas anormales. En: Weatherall DJ. Clínica Hematológica 2/2. Barcelona: Salvat. 1976;A) 319-320 B) 322-323.

10. Carrell RW, Kay R. A simple method for the detection of unstable haemoglobins. $\mathrm{Br}$ J Haematol 1972;23:615-9.

11. Noguera N, Tallano $\mathrm{C}$, Bragós I et al. Modified salting-out method for DNA isolation from newborn cord blood nucleated cells. J Clin Lab Analysis. 2000; 14(6);280-283.
12. Panagoula Kollia, Angelos Kalamaras, Christos Chassanidis, Maria Samara, Nikolaos K. Vamvakopoulos. Compound heterozygosity for the Cretan type of nondeletional hereditary persistence of fetal hemoglobin and $\beta$-thalassemia or $\mathrm{Hb}$ Sabine confirms the functional role of the Ay -158 C>T mutation in $\mathrm{Y}$-globin gene transcription. Blood Cells, Molecules, and Diseases 41. 2008;263-264.

13. Kollia $P$, Kalamaras $A$, Chassanidis $C$ et al. Compound heterozygosity for the Cretan type of non-deletional hereditary persistence of fetal hemoglobin and $\beta$ thalassemia or $\mathrm{Hb}$ Sabine confirms the functional role of the $\mathrm{A} \gamma-158 \mathrm{C}>\mathrm{T}$ mutation in $\mathrm{y}$-globin gene transcription. Blood Cells, Molecules, and Diseases. 2008;41:263264.

14. Eandi Eberle S, Noguera N, Calvo K et al. Severe hemolytic anemia due to hemoglobin Hammersmith. Arch Argent Pediatr. 2009;107(4):347-352.

15. Zanotto MI, Calvo K, Schavartzmanb G et al. Hemolytic anemia due to hemoglobin Evans in an Argentinean family. Arch Argent Pediatr. 2010;108(6):e130-e133.

(c) 2015 Perez et al.; This is an Open Access article distributed under the terms of the Creative Commons Attribution License (http://creativecommons.org/licenses/by/4.0), which permits unrestricted use, distribution, and reproduction in any medium, provided the original work is properly cited.

Peer-review history:

The peer review history for this paper can be accessed here: http://www.sciencedomain.org/review-history.php?iid=1082\&id=28\&aid=9551 